\title{
La Sylphide
}

\section{Katharine Scarlett}

IT IS APPROACHING midnight. The weir manager's daughter lies on her back in bed, awake. She waits, needing to be sure the family are asleep. She listens to the sighs and creaks of the house settling. The hum of the mosquito that has taken up residence in her room. Outside, the carolling of frogs. She hears nothing but the peaceful sounds of night. It is time.

At $8 \mathrm{pm}$ each evening, the weir manager gets into his ute and drives down the short hill to the weir. He turns on the floodlights, both for safety and to signal to visitors that it is time to go home. He drives along the perimeter to make sure everyone has cleared. Then he drives up to the iron gate and padlocks it shut. It is triangular, one flat crossbeam between the top of the two support posts and a second sloping up from the bottom hinge to top corner. It keeps out cars, but little else. Teenagers duck under the high end, slabs of beer under their arms. To guard against this, the weir manager is supposed to do a second drive around two hours later, but it doesn't always happen. So they are free to drink until their eyes bulge, to swim in the moonlight. It is dumb luck that no-one has drowned yet.

Tonight, the weir manager had forgone the second check in favour of watching The Footy Show. He has downed a few beers, and she knows he is 
sleeping soundly. Her brother will be dead to the world. Her mother, well, she can only hope that an attack of insomnia has not struck. She stands before the window in sandals and a dressing gown, sliding up the wide sash window slowly, edging it up inch by inch, until there is space for her to climb through, until she can drop softly between the agapanthus in the garden below. She keeps low passing her parents window, down onto the grass next to the driveway that leads to the weir road.

Her eyes sweep over the scene. The grassed parkland is scattered with gum trees and picnic tables, sloping gently down to water's edge. Families play here on balmy weekends and sometimes on those sweltering evenings where the weir manager keeps the gates open late, because the only other option is to lie prone on the couch with a damp flannel, sticky eyed and desperate for sleep. They bring picnics of roast chicken and salad, play tippity cricket, and swim in the cool clear water.

There is a grass beach of sorts. Further along, it is fringed by weeping willows, their long fronds hanging lazily into the water. Rope swings in varying states of decay hang from the thicker branches.

The grounds appear to be clear enough. Still, she checks again to make sure there are no partying groups. She can't afford to be careless, running down the hill in full view of a pack. She can stand the solitary drunks who leer and call her endearing names as though they are filthy propositions. Groups are a problem.

'What are you doing out so late, sweetie?'

He drags out the first vowel. Sweeee-tie. Relishes it, as he relishes looking at her. She is, after all, sixteen and beautiful. A cascade of auburn hair. Long smooth legs. If he didn't stagger so, he might be threatening, but she can run. If he tried, he would twist his limbs one over the other like a pretzel and crash, nonplussed, onto his back. She does not mind if he sees her, will even play up to an audience, but only if he keeps his distance. He won't ever tell; there is always the risk that a moment of clarity might flash back in the following days, but he'll shake his head in disbelief. 
She skirts the park in the shadow of the gums, following a path that leads to where the river flows into the dam. It is dark, but she has lived here all her life and can predict every twist, ditch and tree root. She navigates her way smoothly, emerging from the gums into a small clearing by the river, and a deep pool ringed by rocks. A single willow leans across the water, over a wide slabby rock. During the day, water dragons lounge here undisturbed, soaking up the sun. At night, the rock is cool.

She skips up onto the rock, facing the water. To the drunk who has blundered after her, it is as though an actress has stepped onto the stage, framed by the proscenium arch of willow fronds, the moon her spotlight. He watches as, slowly, with practiced hands, she loosens her dressing gown belt, letting the knot fall undone.

Is she? Will she? He stares, fixated. Her wide green eyes sparkle with mischief. With a gentle shrug, she slips the gown from her shoulders.

She stands, naked and unearthly pale in the moonlight. Her creamy skin delicately tattooed by dancing shadows, animated by the wind.

So she is going to swim? He grins, a sly grin. He thinks she doesn't see him. That she didn't hear his hefty boots crushing twigs. He waits for her to step into the pool. His mouth is dry with expectation. He wants to see that body in motion, those graceful limbs pushing through the water. To look her up and down from every angle. He wants to pull off his boots and leap in after her.

But she doesn't swim. Instead, she puts both hands to her forehead, curling the fingers and digging the nails in sharply. Working at the skin until she has an edge, an opening, lips of skin she can grasp. She draws it open as one might open curtains, peeling it back. He hears the rip like a torn sheet of cloth as it comes away, the pops of subcutaneous fat bubbles. It sounds violent, but she does it with studied grace. A languid excortication. She gives a little shimmy as she frees it from her hips. Slides it like silk stockings off her legs, kicking them up coquettishly, one at a time. She steps clear as it falls in a wrinkled heap by her dressing gown.

She strikes a pose. Her body shines red. Muscles slick with blood, streaked with pale seams of fat and a lace web of veins. She pauses, giving the drunk a moment to take it all in.

This time, she reaches her right arm across her chest and over her shoulder, pulling at her shoulder blade. She slides her fingers into the tissue to separate it from the shoulder. This is more difficult. In anatomical 
drawings each muscle stands alone, clearly defined. In life, everything is far more connected. It is not like separating the segments of a mandarin. She tugs hard, wrenching off a chunk of shoulder flesh and with it half of a bicep. She moves her hand lower, plucks off the pectoral muscle. She goes on, deft fingers sloughing off hunks of meat. The drunk watches as she tears apart those shapely legs, drops those perfect buttocks at her feet. Tears at her face, throwing off cheeks, eyes, tendons and sinews, to expose the grin beneath. She flashes that outrageous smile indiscriminately, like an actress blinded by lights.

She dives into the pool. Dives into cool melt water that has flowed from high in the mountains, and washes her bones clean. 